\title{
Development of Table Tennis Game Rules Through Modification of Game Rules Model Ams32 in Class VIII Middle School Students
}

\author{
Amal Syahril Sihombing \\ Physical Education \\ Postgraduate of State University \\ of Medan \\ Medan. Indonesia \\ syahreal86@gmail.com
}

\author{
Rahma Dewi \\ Physical Education \\ Postgraduate of State University \\ of Medan \\ Medan. Indonesia
}

\author{
Suprayitno \\ Physical Education \\ Postgraduate of State University \\ of Medan \\ Medan. Indonesia
}

\begin{abstract}
This study aims: (1) Provide an alternative table tennis learning model; (2) Increase the spirit of play; (3) Enriching student movements; (4) Improving effective student movements; (5) Provide input to sports and health physical education teachers for table tennis learning material. Subject collection techniques were purposively Cluster Random Sampling in Class VIII Middle School Students. The data to be used are qualitative data obtained as a whole from the results of questionnaires and portfolios, then it is changed using quantitative data, then made in the form of criticism or input from experts verbally or in writing for product revision materials and research will transform quantitative data into qualitative. Instruments that will be used in developing products are data, observation, interviews, questionnaires. Data analysis techniques used quantitative descriptive analysis techniques with percentages. The results of the study show that: (1) Development of the rules of table tennis game through modification of the game regulation model, students can learn effectively and efficiently so that the problems so far in school learning are due to deficiencies or problems with infrastructure can be modified in the field; (2) Modified game regulation model is expected so that students in learning table tennis game material with rules that can actually be modified according to regulations that have been tested from small groups and large group trials
\end{abstract}

Keywords: modification, game rules, table tennis

\section{INTRODUCTION}

Table tennis game is one of the material in the sports and health physical education unit curriculum that requires adequate facilities and tools starting from the ball, net, table and bed and also the field or room that can be used as a place for the table to play table tennis.

Table tennis games using regulations actually make the game very annoying and boring for students due to the tempo which is quite fast the tempo of the game and also the ball roller are guite past, so students who play the table tennis game feel less satisfied and less happy. Table tennis is a type of sport that is played on a table where the ball is reversed immediately by using a punch called Bad in a table tennis game. [1-5] says that table tennis games may also be played with the idea of reviving the ball as long as possible and may also be played with the idea as quickly as possible to turn off the opponent's game.

In learning physical sports and health education it is necessary to modify learning with equipment variations and rules of the game, then adjust it to the stages of development of students / individuals in order to achieve actual educational goals. So that through modified game rules can make students happy to participate in learning, have fun and be active.

As a result difficult learning material can be presented by playing so that it is easier and can be simplified without having to eliminate the meaning of the purpose of the game itself, because in physical education sports and health students are expected to be active, happy, happy, the goal is so that children can move freely so as to make students are rich in these movements. As [6-12] said that to inspire children to be involved in sports it is necessary to develop modifications in size, weight and equipment design, field size, game rules and number of teams / teams.

The game of table tennis cannot be implemented by students due to several factors such as many students in each class, the difficulty of playing table tennis using actual rules, the tempo of the ball in the game is too fast, and the inefficiency and effectiveness of the need for facilities and infrastructure with the number of students who will use it and less [13-16].

\section{RESEARCH METHODS}

The initial research was conducted at Medan Middle School 14, then research on trial products at Medan 14 Public Middle School, Medan Public Middle School 13, then product research in Medan 12 Public Middle School, Medan 27 Public Middle School, and Medan 35 Public Middle School. The time of the study was carried out in November 2018 with table 
tennis learning materials in each school to adjust the research material.

\section{A. Research Objectives}

The aim of the research in the development of tennis game rules was through a modified model of tennis game rules for class VIII students and sports and health physical education teachers

\section{B. Research subject}

The subject taking technique applied in this research development is Purposive Cluster Random Sampling which is also known as consideration sample or based on consideration of the number of classes and certain random samples.

\section{Data collection technique}

The data used from the development of game rules through modification of the rules of tennis games is qualitative data. After the qualitative data was obtained as a whole from the results of the questionnaire and portfolio, it was changed using quantitative data, then made in the form of criticism or input from experts verbally and in writing for material for product revision and research to change quantitative data into qualitative

\section{Validation, Evaluation, Model Revision}

Developers of the table tennis game through a modification of the rules of the tennis game were validated by experts namely physical education lecturers who were appointed directly by the PPs Unimed Sports Education Study Program, then the evaluation and revision of the model starting from the initial trials, field trials 1, and field trials 2 conducted by experts or experts who are qualified in their field.

\section{E. Research Development Steps}

Research on the development of table tennis game rules through modification of the tennis game regulation model for junior high school students of class VIII consists of three stages, with the design modified and harmonized with the actual objectives and conditions of the study, as illustrated in the following table:

TABLE 1. STAGES OF DEVELOPMENT RESEARCH

\begin{tabular}{lll}
\hline \multicolumn{1}{c}{ Stage } & Step & \multicolumn{1}{c}{ Activity } \\
\hline \multirow{2}{*}{$\begin{array}{l}\text { Pre- } \\
\text { Development }\end{array}$} & 1 & $\begin{array}{l}\text { (a) Initial data collection; (b) } \\
\text { Preparation of research } \\
\text { proposals; (c) Need analysis. }\end{array}$ \\
\cline { 2 - 3 } & 2 & Learning planning \\
\cline { 2 - 3 } Development & 3 & Learning \\
\hline & $\begin{array}{l}\text { Formative evaluation: } \\
\text { Initial trial (1) } \\
\text { Phase I expert judgment with } \\
\text { physical education learning } \\
\text { experts. } \\
\text { Initial Repair (1) }\end{array}$ \\
\cline { 2 - 3 } & & Initial trial (2) \\
\hline
\end{tabular}

$5 \quad$ Phase I expert judgment with physical education learning experts.

Initial Repair (2)

Field trials

6 Evaluation with a limited

Penerapan scale of 30 subjects

$7 \quad$ Operational Improvement Application / dissemination

\section{F. Data Collection Instruments}

The instrument used to collect data was in the form of evaluation sheets and questionnaires. Evaluation sheets are used to collect data from experts related to the developed model, whether it has been effective and efficient for learning physical sports education and health. Questionnaires for experts and for students are used to collect data from expert evaluations and in trials.

The questionnaire used for experts in the form of a number of assessed eligibility. The factors used in the questionnaire are the quality of the rules of the tennis game, as well as general comments and suggestions, if any.

The range of evaluations made by scoring:

checklist $(\mathbf{V}) \quad \rightarrow$ score 2 (students moves according to portfolio sheet)

not checklist $(\mathbf{V}) \rightarrow$ score 1 (if not suitable)

Questionnaires used by students in the form of a number of questions that must be answered by students with alternative answers "Yes" or "No". Factors used in the questionnaire included psychomotor, cognitive, affective aspects.

\section{G. Data analysis}

The validity test of this test uses the expert justification test, the declared valid instrument is compiled from the results of consultations with experts including: table tennis practitioners, physical education experts, educational technology practitioners and physical education teachers.

In this research development the data analysis technique used is quantitative descriptive analysis technique with a percentage. This technique is used to analyze quantitative data obtained from the distribution of evaluation questionnaires from athletic experts / trainers and physical education learning experts regarding the results of products developed [17-20].

The analysis used is descriptive analysis, which aims to determine the value of psychomotor. Formula used:

$$
\text { Value }=\frac{\text { Total score obtained }}{\text { Total score }} \times 100
$$

\section{RESULTS AND DISCUSSION}

The results of the questionnaire interviews were conducted with several teachers and students at SMPN 12 
Medan, SMPN 13 Medan, SMP 14 Medan. From the analysis it is known that: (a) $22.86 \%$ of students did not know about table tennis and $72.14 \%$ knew; (b) $9 \%$ of students had difficulty learning table tennis games $40 \%$ were difficult, $31.43 \%$ found it quite difficult to play table tennis and $2.86 \%$ of students found it easy; (c) $100 \%$ of students feel bored playing table tennis with actual rules; (d) $2.86 \%$ of students like table tennis, $8.57 \%$ of students like rhythmic gymnastics, $82.86 \%$ of students like playing soccer, and $5.71 \%$ of students like the athletics; (e) $88.57 \%$ of students expect the rules of the game of table tennis to be modified $11.43 \%$ do not need to be modified; (f) $85.71 \%$ of students felt confident that the rules of the table tennis game were modified students could be more motivated in playing table tennis $8.57 \%$ of students felt less confident and $5.71 \%$ of students felt unsure. So it is stated that most students find it difficult to play table tennis with the actual rules, RPP and syllabus of teachers who do not and lack of modifying the rules of the game that can stimulate students less fond and happy in playing table tennis itself, so the development of table tennis game rules is very carried out how to modify the rules with the rules of table tennis games for table tennis game materials for junior high school students of class VIII.

All attachments of expert evaluation instruments for teaching materials in learning table tennis games, expert fortopolio instruments in table tennis games were validated and revised validation results by physical education experts, physical education teachers and practitioners of table tennis games as well as physical education technology practitioners. A valid instrument from the expert then carried out the development of table tennis game rules through modification of the rule model in a trial of a small group of 30 students in SMP Negeri 13.

\section{Product Testing Results}

After developing the rules of the table tennis game through modification of the game rules model for eighth grade junior high school students tested on a small scale overall the subjects 30 test students obtained a score of 498 from a maximum score of 720 or with an average of $69 \%$ and an evaluation of the Phase I expert portfolio of $80 \%$ with the category "valid enough" so that the use of the modification game rules model can be categorized as suitable although it needs to be improved because the results of the Phase I trial still have some instruments that need to be improved by experts, then the results of the initial product revision used for trials in large groups. The effectiveness of the modified regulatory model is determined by the criterion score for the learning model.

An ideal score $=1 \times 2 \times 12 \times 30=720$

Note: 1 scores the lowest value, 12 the number of instruments,

2 scores highest scores, 30 many respondents.

then the effectiveness of the modified table tennis game rules model as a whole is the total overall value divided by the ideal score $=498: 720=0.69$ or $69 \%$, so it is said that "enough" criteria are less expected.

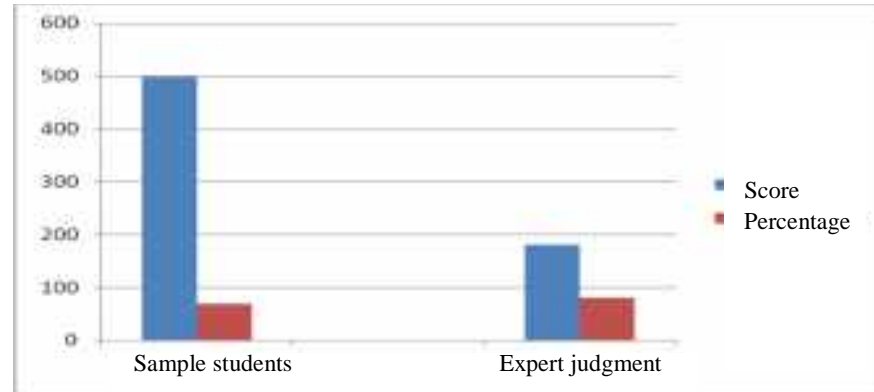

Based on the results of large group trials conducted on the subject of 70 students with modified rules obtained a score of 1561 from a maximum score of 1680 or the average percentage of the results of the use of table tennis game development with modified rules of $93 \%$ and the results of the Phase II expert evaluation portfolio by $91 \%$ with the "Valid" category, then calculates the average effectiveness of the game rules model by modification in stage II with the learning model criterion score.

An ideal score $=1 \times 2 \times 12 \times 70=720$

Note: 1 scores the lowest value, 12 the number of instruments, 2 scores highest scores, 30 many respondents.

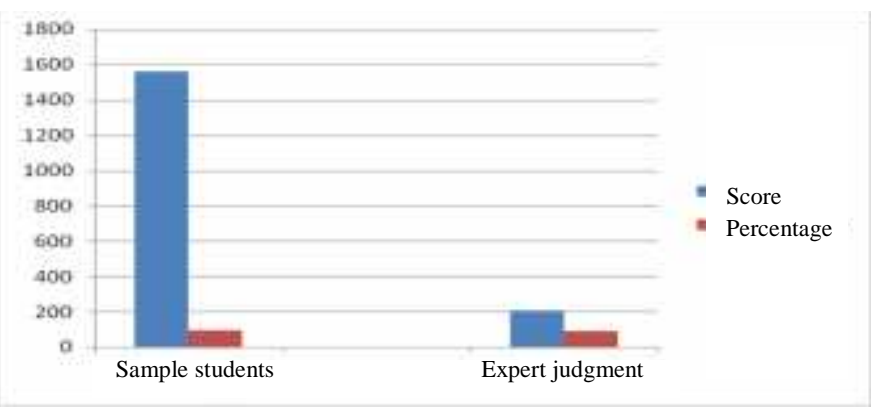

thus the effectiveness of the modified table tennis game rules model as a whole is the overall total score divided by the ideal score $=1561: 680=0.93$ or $93 \%$ said to be "Valid" expected criteria, the development of table tennis game rules by using modified rules can be categorized as Valid and suitable for use in learning table tennis games at school for junior high school students grade VIII. According to the expert opinion in the second phase of the trial, there is no need for revision because it meets the standards for product dissemination by testing the effectiveness and efficiency in the learning process.

Some limitations of the material considerations in generalizing the results of research achieved include: (1) Field research trials conducted at five schools where in the application of some students are still less enthusiastic in doing it; (2) The existence of psychological factors that are suspected to have influenced the results of research that cannot be controlled include: when the physical condition is not healthy, self-confidence, and other psychological factors.

\section{IV.CONCLUSION}

Based on the data obtained, from the results of small group trials and large group trials in the field as well as the results of 
the study, it was concluded that: (1) Development of table tennis rules through modification of the rules model of ams tennis game 32 can be used as an alternative to student table tennis games at school ; (2) Through the development of the ams 32 tennis game rules making students more enthusiastic in playing table tennis in physical education and sports learning health; (3) With the development of the ams 32 tennis game rules, it can be a way to enrich student movements when learning physical sports and health education; (4) Development of table tennis game rules through modification of ams 32 tennis game rules one way to improve student motion more effectively; (5) As an input to physical and health physical education teachers to enrich the treasury for modifying table tennis games and other game materials available in physical and health physical education learning.

\section{REFERENCES}

[1] Chairuddin Hutasuhud (1988). Tenis Meja Istitut Keguruan dan Ilmu Pendidikan. Padang.

[2] Ahmad Paturusi (2012). Manajemen Pendidikan Jasmani dan Olahraga. Jakarta; Rineka Cipta.

[3] Ali Muhammad (1987). Penelitian kependidikan Prosedur dan Strategi. Bandung: Angkasa.

[4] A.M. Bandi Utama. (2004). Kemampuan bermain Tenis Meja. Studi Korelasi Antara Kelincahan dan Kemampuan Pukulan Dengan Kemampuan Bermain Tenis Meja. Laporan Penelitian. Yogyakarta: FIK UNY.

[5] Amung Ma'mun.2000.Perkembangan Gerak dan Belajar Gerak. Depdiknas.

[6] Albadi dan Nono (2014). Teori Dasar Motor Kontrol Dalam Pendidikan Jasmani dan Olahraga Pada Usia Dini. Medan; Unimed Press..

[7] Badan Standar Nasional Pendidikan.2006. Model Kurikulum Tingkat Satuan Pendidikan Dan Model Silabus Mata Pelajaran SD/MI. Jakarta: BP.Cipta Jaya.

[8] Bakker, Theo. 1987. Tenis Meja. Jakarta: PT Rosda Jaya Putra.

[9] Brooks dan Elliot. 1971. Pengertian Definisi Bermain. (Online), (http://carapedia. com/pengertian_definisi_bermain_info2105. html, accessed January 2, 2012.

[10] Daryono. 2014. Pengembangan Model Permainan Bola Basket Ring Ball Siswa SMP Se-Kecamatan Lubuk Raja Oku. Jurnal keolahragaan. 12(3): 22.

[11] Drowazky, J.V.et.al. (1984). Physical Education Career Oerspectives and Profesional Foundations. Englewood Cliff, N.J. : Prentice Hall Inc

[12] Desmita (2010). Psikologi Perkembangan Peserta Didik. Bandung; PT.Remaja Rosdakarya.

[13] Ega Trisna Rahayu (2013).Strategi Pembelajaran Penjas. Bandung: Alfabeta.

[14] Elizabeth, B. Hurlock (1955). Psikologi Perkembangan. Jakarta; Erlangga.

[15] Sapto Adi \& Mu'arifin. (1994). Sosiologi Olahraga. Upt Perpus Um, Malang.

[16] Setyosari, Punaji dan Sultan (2003). Metode Penelitian Pendidikan dan Pengembangan. Jakarta: Kencana Prenada Media Group

[17] Emzir (2014). Metodologi Penelitian pendidikan kuantitatif dan kualitatif. Jakarta: Rajawali Pers.

[18] Gallahue, L David and John C. Ozmun (2006). Understanding Motor Development: Infants, Children, Adolescents, Adults. New York: McGraw-Hill.

[19] Kertamanah Alex (2003). Teknik dan Taktik Dasar Permainan Tenis Meja. Jakarta; Grafindo Persada.

[20] Larry Hodges. (1996). Tenis Meja untuk Pemula. Jakarta : Raja Grafindo Persada 